\title{
Genotyping of Toxoplasma gondii and Sarcocystis spp. in road-killed wild mammals from the Central Western Region of the State of São Paulo, Brazil
}

\author{
Virgínia Bodelão Richini-Pereira[1], Pâmela Merlo Marson ${ }^{[2],}$ \\ Rodrigo Costa da Silva ${ }^{[3]}$, and Helio Langoni ${ }^{[2]}$
}

\begin{abstract}
[1]. Laboratório Regional de Bauru, Instituto Adolfo Lutz, Bauru, São Paulo, Brasil. [2]. Departmento Higiene Veterinária e Saúde Pública, Faculdade de Medicina Veterinária e Zootecnia, Universidade Estadual Paulista, Botucatu, São Paulo, Brasil. [3]. Department of Pathobiology and Population Medicine, College of Veterinary Medicine, Mississippi State University, Mississippi State MS, USA.
\end{abstract}

\begin{abstract}
Introduction: Road-killed wild animals host zoonotic pathogens such as Toxoplasma gondii, offering a new opportunity for the epidemiological study of these infectious organisms. Methods: This investigation aimed to determine the presence of T. gondii and other apicomplexan parasites in tissue samples of 64 road-killed wild animals, using polymerase chain reaction (PCR). Positive samples were then typed by PCR-restriction fragment length polymorphism (RFLP) using 7 markers: SAG1, 5'-3'SAG2, SAG3, BTUB, c29-6, PK1, and Apico. PCR-RFLP targeting 18S ribosomal RNA (rRNA) genes was also performed on all samples to detect other apicomplexan parasites. Results: T. gondii DNA was detected in 16 tissue samples from 8 individual animals, as follows: 1 Cerdocyon thous (crab-eating fox), 1 Didelphis albiventris (white-eared opossum), 1 Lutreolina crassicaudata (lutrine opossum), 2 Myrmecophaga tridactyla (giant anteater), 1 Procyon cancrivorus (crab-eating raccoon), and 2 Sphiggurus spinosus (Paraguay hairy dwarf porcupine). Seven different $T$. gondii genotypes were identified, 6 of which were novel. Typing by $18 \mathrm{~S}$ rRNA verified these 16 T. gondii-infected samples, and identified 1 Sarcocystis spp.-infected animal [Dasypus novemcinctus (nine-banded armadillo)]. The amplified T. gondii (GenBank accession No. L37415.1) and Sarcocystis spp. 18S rRNA products were confirmed by sequencing. Conclusions: Our results indicate that $T$. gondii is commonly present in wild mammals, which act as sources of infection for humans and animals, including other wild species. The approach employed herein proved useful for detecting T. gondii and Sarcocystis spp. in the environment and identifying their natural reservoirs, contributing to our understanding of host-parasite interactions.
\end{abstract}

Keywords: Road-killed animal. Toxoplasma gondii. Sarcocystis spp. Genotyping. Molecular techniques.

\section{INTRODUCTION}

Several pathogens derive from wild animals, the study of which is becoming increasingly restrictive, especially when euthanasia is required. Thus, road-killed wild mammals offer an alternative source of such animals for research involving molecular detection of parasites. Although microbiological culture and histopathological analysis using tissue samples from road-killed wild animals are challenging, the identification and typing of pathogens can be achieved through molecular methods ${ }^{(1)}$.

Apicomplexan parasites, principally Toxoplasma gondii, are very common among domestic and wild animals. T. gondii is an obligate intracellular protozoan parasite, prevalent in animals worldwide, and commonly infecting humans. Infection

\footnotetext{
Corresponding author: Dr. Helio Langoni.

e-mail: hlangoni@fmvz.unesp.br

Received 30 June 2016

Accepted 13 September 2016
}

can occur by transplacental transmission, oral ingestion of contaminated soil, raw vegetables, fruits, or water containing sporulated oocysts shed by definitive hosts in their feces, or by ingestion of tissue cysts in raw or undercooked meat or viscera of intermediate hosts ${ }^{(2)(3)}$. This parasite exhibits a highly complex clonal genetic population structure that has been extensively studied in recent years ${ }^{(4)}$. Several regions of the T. gondii genome have been used for the identification of this organism. The 529- base pair (bp) repetitive sequence, which repeats 200300 times per genome, provides high sensitivity and specificity, representing an important target for identification ${ }^{(5)(6)}$. Toxoplasma gondii comprises several clonal lineages whose pathogeneses in humans and animals may differ in progression and severity ${ }^{(7)}$.

Thus, research concerning the identification of $T$. gondii by molecular techniques in novel hosts is crucial to clarify its interactions with hosts and molecular epidemiology, and may also provide a good indicator of environmental contamination. Wild animals act as reservoirs of $T$. gondii infection affecting humans and food animals, necessitating the adoption of 
epidemiological and sanitary control measures. With this in mind, the present study aimed to identify new hosts of $T$. gondii and other apicomplexan parasites in tissue samples of roadkilled wild mammals using molecular techniques. In addition, parasite genotypes in circulation were determined.

\section{METHODS}

\section{Animals}

Sixty-four road-killed wild animals were studied: 1 Callithrix penicillata (black-pencilled marmoset) (A1); 4 Cavia aperea (Brazilian guinea pig) (A2-A5); 1 Cebus apella (tufted capuchin) (A6); 12 Cerdocyon thous (crabeating fox) (A7-A18); 3 Dasypus novemcinctus (nine-banded armadillo) (A19-A21); 1 Dasypus septemcinctus (Brazilian lesser long-nosed armadillo) (A22); 8 Didelphis albiventris (white-eared opossum) (A23-A30); 1 Eira barbara (tayra) (A31); 1 Euphractus sexcinctus (yellow armadillo) (A32); 2 Galictis vittata (greater grison) (A33, A34); 2 Hydrochoerus hydrochaeris (capybara) (A35, A36); 3 Leopardus tigrinus (oncilla) (A37-A39); 3 Lepus europaeus (European hare) (A40-A42); 2 Lutreolina crassicaudata (lutrine opossum) (A43, A44); 2 Mazama gouazoubira (gray brocket) (A45, A46); 1 Myocastor coypus (coypu) (A47); 5 Myrmecophaga tridactyla (giant anteater) (A48-A52); 3 Procyon cancrivorus (crab-eating raccoon) (A53-A55); 1 Puma concolor (puma) (A56); 2 Rattus rattus (house rat) (A57, A58); 4 Sphiggurus spinosus (Paraguay hairy dwarf porcupine) (A59-A62); and 2 Tamandua tetradactyla (southern tamandua) (A63, A64). Only wild animals with no exposed viscera killed $1-7$ hours prior to being processed in the laboratory were studied. This study is in accordance with Instituto Brasileiro do Meio Ambiente e dos Recursos Naturais Renováveis (IBAMA) normative statement $\mathrm{n}$. 119 of October 11, 2006, Chapter VI, Art. 26, which authorizes the sampling and transport of road-killed wild animals.

\section{Ethical considerations}

This work was also approved by the Animal Experimentation Ethics Committee, Faculdade de Medicina Veterinária e Zootecnia, Universidade Estadual Paulista (CEEA/FMVZ n. 052/05).

\section{Sampling}

All animals were transported at $4{ }^{\circ} \mathrm{C}$ to the FMVZ. Lung, spleen, liver, kidney, heart, and mesenteric lymph node samples were collected from each animal, finely chopped, and stored at $-80^{\circ} \mathrm{C}$ in $1.5-\mathrm{mL}$ centrifuge tubes containing sterilized ultrapure water (Life Technologies, Carlsbad, CA, USA), until needed for Deoxyribonucleic acid (DNA) extraction.

\section{Molecular detection}

DNA extraction was carried out using an illustra tissue \& cells genomicPrep Mini Spin Kit (GE Healthcare, Chicago, IL, USA) according to the manufacturer's instructions. Polymerase chain reactions (PCRs) were run using the following primers targeting a 529-bp repetitive sequence in the $T$. gondii genome $^{(5)}$ : TOX4 (5'-CGCTGCAGGGAGGAAGACGAAAGTTG-3') and TOX5 (5'-CGCTGCAGACACAGTGCATCTGGATT-3'). Each reaction contained $10 \mathrm{mM}$ Tris- $\mathrm{HCl}(\mathrm{pH} 8.0), 50 \mathrm{mM} \mathrm{KCl}$, $1.5 \mathrm{mM} \mathrm{MgCl}_{2}, 0.2 \mathrm{mM}$ deoxynucleotides (Life Technologies), 10pmol each primer (Integrated DNA Technologies, Coralville, IA, USA), 0.2 units Taq DNA polymerase (Life Technologies), and 10ng DNA template. All reactions were run on a MasterCycler ep Gradient instrument (Eppendorf, Hauppauge, NY, USA), using the following cycling protocol: initial denaturation for 7 minutes at $94^{\circ} \mathrm{C}$, followed by 35 cycles of 1 minute at $94^{\circ} \mathrm{C}, 1$ minute at $60^{\circ} \mathrm{C}$, and 1 minute at $72^{\circ} \mathrm{C}$, before a final extension for 10 minutes at $72^{\circ} \mathrm{C}$. Amplicons were analyzed by electrophoresis in $1.5 \%$ agarose with SYBR Safe DNA gel stain (Life Technologies), and recorded using a digital gel documentation system, GelDoc-ITTM Imaging System (UVP, Upland, CA, USA).

Toxoplasma gondii typing was performed using seven genetic markers (SAG1, 5'-3'SAG2, SAG3, BTUB, c29-6, PK1, and Apico), as previously described ${ }^{(8)(9)(10)(11)}$. Reference strains (GT1, PTG, CTG, TgCgCa1, MAS, and TgCatBr5) were used as reaction controls. The multiplex PCR products were used in nested PCRs specific to each marker, and restriction fragment length polymorphism (RFLP) was then applied to obtain a profile for each sample. All products were visualized by electrophoresis on a 2.5 or $3 \%$ agarose gel (depending on the marker under examination) stained with SYBR Safe DNA gel stain, and imaged using a digital gel documentation system as above.

The identification of apicomplexan parasites other than T. gondii in the studied samples was carried out by molecular methods developed to target the $T$. gondii $18 \mathrm{~S}$ ribosomal ribonucleic acid (rRNA) gene, as described by Da Silva et al. ${ }^{(12)}$. A nested PCR was performed using $25 \mu \mathrm{M}$ external primers Tg18s $48 \mathrm{~F}$ (5'-CCATGCATGTCTAAGTATAAGC-3') and Tg18s359R (5'-GTTACCCGTCACTGCCAC-3'), and $50 \mu \mathrm{M}$ internal primers Tg18s58F (5'-CTAAGTATAAGCTTTTATACGGC-3') and Tg18s348R (5'-TGCCACGGTAGTCCAATAC-3') (Integrated DNA Technologies), expected to amplify products of 290bp for Neospora caninum, Hammondia hammondi, and T. gondii, and $\sim 310 \mathrm{bp}$ for Sarcocystis spp. (except Sarcocystis neurona). All nested PCR products were confirmed by RFLP ${ }^{(12)}$ and sequencing. Reactions were carried out on a MasterCycler ep Gradient instrument, and 1.5\% agarose gel electrophoresis was used to gauge the quantity and quality of the resulting products. Sequencing was carried out at the facilities of the UNESP Biosciences Institute.

\section{RESULTS}

Table 1 contains the taxonomy, sex, and geographic location of the road-killed wild animals for which positive PCR results for T. gondii and Sarcocystis spp. DNA were obtained, and Table 2 details the corresponding tissue samples and parasite identities. Genotyping results are presented in Table $3^{(8)(10)(13)(14)(15)(16)(17)}$.

Cerdocyon thous was the most frequently observed species [12/64, 18.6\%; 95\% confidence interval (CI): 11.1-30.0\%]. Of the 8 T. gondii-positive samples, 2 were from members of Carnivora (1 C. thous and 1 P. cancrivorus), 2 from Rodentia 


\section{TABLE 1}

Taxonomy, sex, and geographic location of PCR-positive road-killed wild animals.

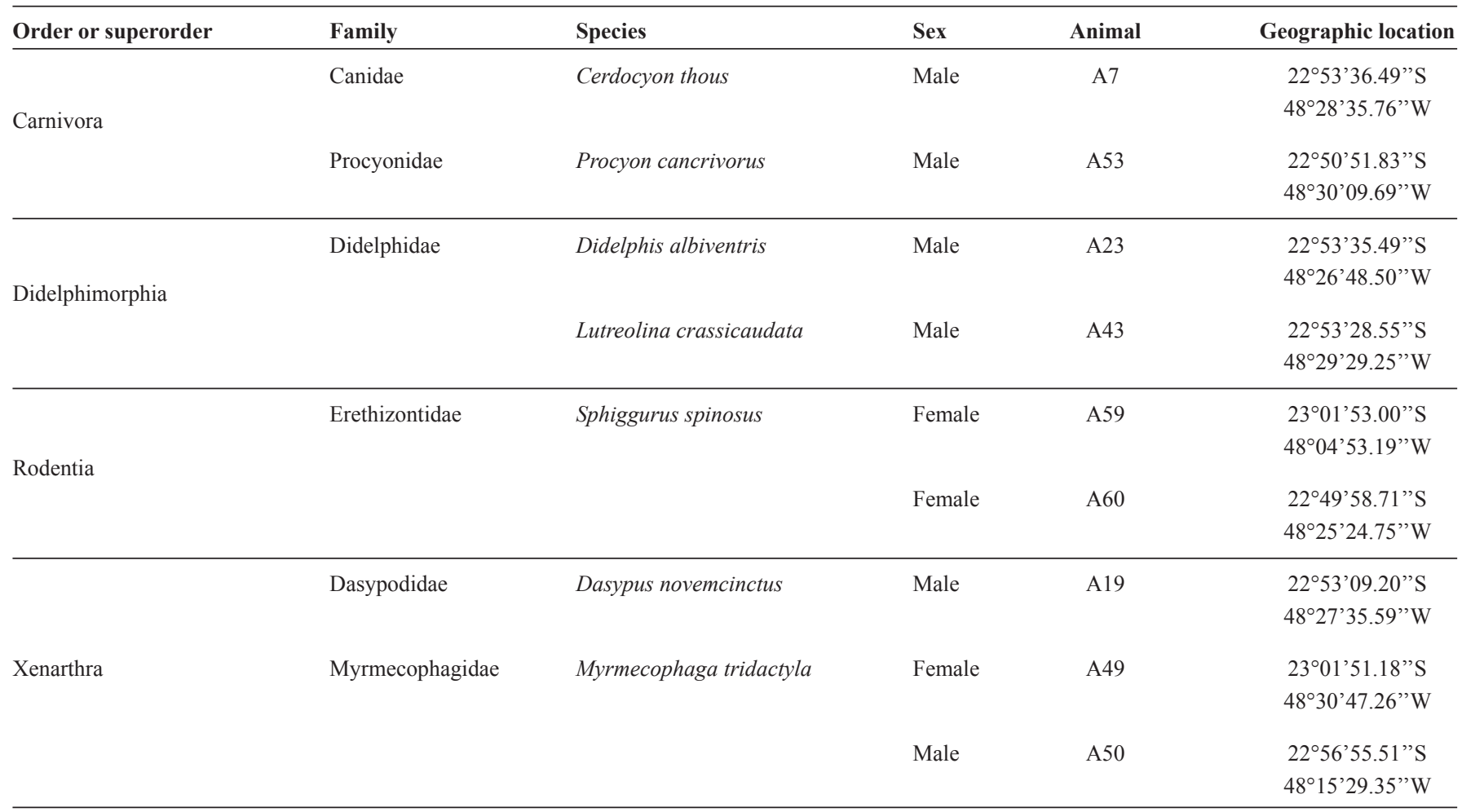

PCR: polymerase chain reaction.

TABLE 2

Molecular identification by PCR and sequencing of Toxoplasma gondii and Sarcocystis spp. in tissue samples from road-killed animals.

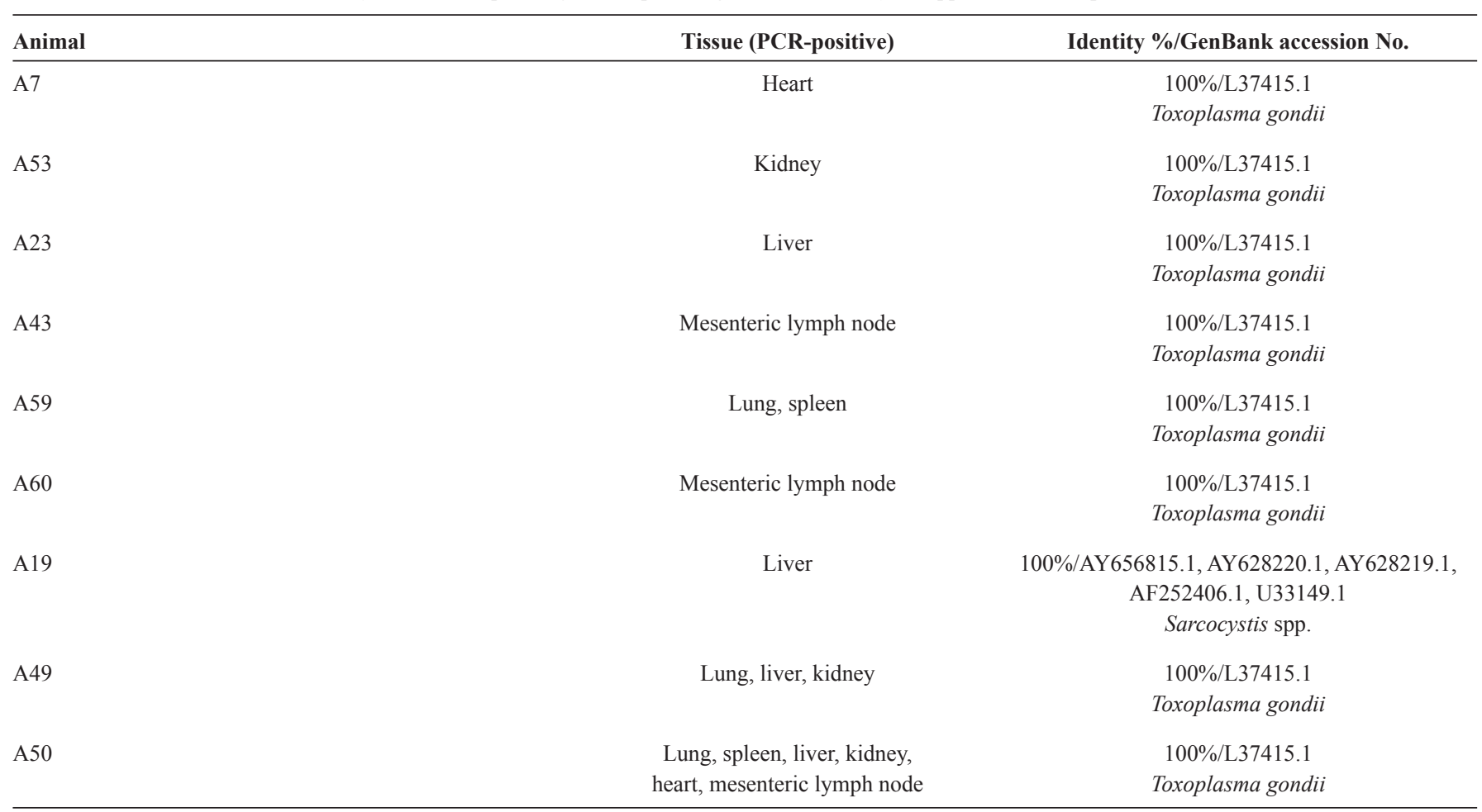

PCR: polymerase chain reaction; RNA: ribonucleic acid; GenBank accession No.: L37415.1: Toxoplasma gondii 18S ribosomal RNA gene, complete sequence; AY656815.1: Sarcocystis felis sporocysts small subunit ribosomal RNA gene, partial sequence; AY628220.1: Sarcocystis falcatula strain Stiles small subunit ribosomal RNA gene, partial sequence; AY628219.1: Sarcocystis neurona isolate MIOP17 small subunit ribosomal RNA gene, partial sequence; AF252406.1: Sarcocystis neurona 18S ribosomal RNA gene, partial sequence; U33149.1: Sarcocystis neurona 18S small subunit ribosomal RNA gene, 5' partial sequence. 
TABLE 3

Genotypic profiles of Toxoplasma gondii identified in tissue samples from road-killed animals.

\begin{tabular}{|c|c|c|c|c|c|c|c|c|c|}
\hline \multicolumn{10}{|c|}{ Genetic marker } \\
\hline Animal & SAG1 & 5'-3'SAG2 & SAG3 & BTUB & c29-6 & PK1 & Apico & Genotype & Reference \\
\hline A7 & $\mathrm{u}-1$ & III & III & no data & no data & no data & I & Unique & Present study \\
\hline A23 & II/III & $\mathrm{I} / \mathrm{II}$ & III & no data & I & no data & I & Unique & Present study \\
\hline A43 & II/III & $\mathrm{I} / \mathrm{II}$ & III & no data & I & no data & I & Unique & Present study \\
\hline A49 & II/III & no data & III & no data & I & no data & I & Unique & Present study \\
\hline A59 & II/III & I & III & III & no data & no data & I & Unique & Present study \\
\hline A60 & I & I & III & III & II & III & I & Unique & Present study \\
\hline \multirow[t]{6}{*}{ A50 } & $\mathrm{u}-1$ & no data & III & III & I & no data & I & CASTELLS & (13) \\
\hline & & & & & & & & MAS & (8) \\
\hline & & & & & & & & $\operatorname{TgDgBr} 15$ & (10) \\
\hline & & & & & & & & TgCkBr14 & (15) \\
\hline & & & & & & & & $\mathrm{TgCkBr} 45$ & (16) \\
\hline & & & & & & & & $\mathrm{TgCkNg} 1$ & (17) \\
\hline
\end{tabular}

(1 Sphiggurus spinosus), 2 from Didelphimorphia (1 L. crassicaudata and $1 D$. albiventris), and 2 from Xenarthra (1 $M$. tridactyla). One sample from a species in this latter order $(1 D$. novemcinctus) tested positive for Sarcocystis spp. Seven of the 8 T. gondii isolates in the present study exhibited novel genotypes.

\section{DISCUSSION}

Utilizing road-killed wild animals for molecular detection of T. gondii represents a feasible and efficient alternative to the use of live animals in research, as indicated by animal research ethics committees. Notably, most studies having used road-killed wild animals have identified a large number of mammalian species. In addition, sensitive and specific molecular tools enable pathogen identification without the need for laborious microbiological cultures and histopathological examination.

In this paper, molecular detection of $T$. gondii in several wild species was attempted using PCR. A number of studies have reported the presence of this parasite in wild rodents and members of Carnivora, Didelphimorphia, and Xenarthra ${ }^{(18)(19)(20)}$. These findings confirm the worldwide distribution of T. gondii, and highlight the wide variety of intermediate hosts that form part of the epidemiological chain responsible for transmission of this infection and the associated disease.

Here, 22 specimens were from members of the order Carnivora, with $C$. thous predominating. These animals can be found in several environments, from Cerrado savanna to the Atlantic Forest ${ }^{(21)}$. Their abundance may be due to their generalist and, of preference, nocturnal feeding habits, moving through tracks at forest edges and surviving in degraded and anthropic areas $^{(22)}$. They are frequently seen on roadsides searching for food, which may include other road-killed animals, meaning that, as a carnivorous species, C. thous has a high road-kill rate ${ }^{(23)}$. T. gondii DNA was detected in samples from $1 C$. thous and $1 P$. cancrivorus. In the literature, similar results have been obtained using molecular assays ${ }^{(20)(24)}$.

Toxoplasma gondii DNA was not detected in animals of the orders Artiodactyla (2 M. gouazoubira), Lagomorpha (3 L. europaeus), and Primates (1 C. apella and 1 C. penicillata), but these groups are nevertheless important in the epidemiology of this parasite, since several reports of $T$. gondii infection in cervids, lagomorphs, and primates have been published ${ }^{(25)}$.

Toxoplasma gondii DNA was detected in 2/13 (15.4\%) specimens of the order Rodentia. The positive $S$. spinosus samples emphasize the importance of this species as a carrier of T. gondii and several other pathogens with zoonotic potential ${ }^{(26)}$. Although the number of infected animals of this order was small, further assessment of this group is needed, since Truppel et al. ${ }^{(27)}$ and Yai et al. ${ }^{(28)}$ successfully isolated this parasite from capybaras (H. hydrochaeris), detecting its presence by serology.

Members of Didelphidae, represented here by $D$. albiventris and L. crassicaudata (10 specimens), are generalists and inhabit areas close to human dwellings, including farms, backyards, and urban centers ${ }^{(29)}$. Due to the destruction of their habitat, L. crassicaudata seeks shelter and food in urban areas ${ }^{(28)}$. This group is considered a reservoir of several potentially zoonotic organisms $^{(30)}$. In our study, T. gondii DNA was detected in 1 L. crassicaudata and 1 D. albiventris. 
Of the 12 animals belonging to the superorder Xenarthra, 3 (25\%; 95\%CI: 9.1-53.8\%) gave positive PCR results, 1 for Sarcocystis spp. This reinforces the importance of this taxon in the epidemiology of $T$. gondii infection. The fact that this parasite was not detected in E. sexcinctus may reflect the differences between this animal's feeding habits and habitat and those of the other species examined. E. sexcinctus feeds on carrion found on the ground, and constructs its burrows in drier environments and open fields ${ }^{(21)}$.

Toxoplasma gondii samples from 8 animals were genotyped, 7 of which yielded previously unreported marker combinations (Table 3), and 1 of which demonstrated a profile similar to that already reported in RFLP studies performed by Dardé(13), Su et al. ${ }^{(8)}$, Sousa et al. ${ }^{(15)}$, Dubey et al. ${ }^{(10)(16)}$, and Velmurugan et al. ${ }^{(17)}$. Two of these genotypes, $\mathrm{TgCatBr} 38$ and TgCatBr44, were identified in cats from Araçatuba and Conchas, both in the State of São Paulo ${ }^{(14)}$. In contrast to Pena et al. ${ }^{(14)}$, in this study, typing data was obtained from only 7 of the markers tested. It is likely that the remainder were negative due to low parasite loads. Having complete typing data for all 11 markers would certainly provide a more accurate picture of the present study sample. However, the 7 unique results obtained emphasize the importance of wild animals and the utility of road-killed specimens to the study of pathogens causing infectious diseases. The distinctiveness of these genotypes demonstrates that $T$. gondii is constantly adapting to its environment, as observed by $\mathrm{Su}$ et al ${ }^{(8)}$, Pena et al. ${ }^{(14)}$, and Da Silva et al..$^{(4)}$, with mutations and adaptive changes in clonal populations. Most of the animals identified in this work become infected through different routes. Therefore, further study of these species may provide valuable epidemiological information, supplying answers to the many questions concerning the adaptation and transmission of $T$. gondii to new hosts, its resistance, and the development of future vaccines.

Thus, road-killed wild animals may serve as an important T. gondii reservoir, contributing to its transmission to domestic and wild animals, as well as humans.

\section{Acknowledgments}

We are grateful to the Departamento de Estradas de Rodagem do Estado de São Paulo (DER/SP), as well as Prof. Dr. Reinaldo José da Silva, Lucilene Granuzzio Camossi, and Juliana Griese for information regarding the roadkilled animals.

\section{Conflict of interest}

The author declares there is no conflict of interest.

\section{Financial Support}

This study was supported by the Fundação de Amparo à Pesquisa do Estado de São Paulo (FAPESP \#08/09378-8 and \#08/08291-6).

\section{REFERENCES}

1. Bowman BH. A model PCR/probe system for the identification of fungal pathogens. In: Persing DH, Smith TF, Tenover FC, White TJ, editors. Diagnostic molecular microbiology: principles and applications. Cap. 3, Washington, DC: American Society for Microbiology; 1993. p. 423-430.

2. Dubey JP, Jones JL. Toxoplasma gondii infection in humans and animals in the United States. Int J Parasitol 2008; 38:1257-1278.

3. Kijlstra A, Jongert E. Control of the risk of human toxoplasmosis transmitted by meat. Int J Parasitol 2008; 38:1359-1370.

4. Da Silva RC, Langoni H, Su C, Da Silva AV. Genotypic characterization of Toxoplasma gondii in sheep from Brazilian slaughterhouses: new atypical genotypes and the clonal type II strain identified. Vet Parasitol 2011; 175:173-177.

5. Homan WL, Vercammen M, De Braekeleer J, Verschueren H. Identification of a 200- to 300-fold repetitive 529 bp DNA fragment in Toxoplasma gondii, and its use for diagnostic and quantitative PCR. Int J Parasitol 2000; 30:69-75.

6. Edvinsson B, Lappalainen M, Evengard B. Real-time PCR targeting a 529-bp repeat element for diagnosis of toxoplasmosis. Clin Microbiol Infect 2006; 12:131-136.

7. Howe DK, Sibley LD. Toxoplasma gondii comprises three clonal lineages: correlation of parasite genotype with human disease. J Infect Dis 1995; 172:1561-1566.

8. Su C, Zhang X, Dubey JP. Genotyping of Toxoplasma gondii by multilocus PCR-RFLP markers: a high resolution and simple method for identification of parasites. Int J Parasitol 2006; 36: 841-848.

9. Ferreira AM, Vitor RW, Gazzinelli RT, Melo MN. Genetic analysis of natural recombinant Brazilian Toxoplasma gondii strains by multilocus PCR-RFLP. Infect Genet Evol 2006; 6:22-31.

10. Dubey JP, Gennari SM, Sundar N, Vianna MCB, Bandini LM, Yai LE, et al. Diverse and atypical genotypes identified in Toxoplasma gondii from dogs in São Paulo, Brazil. J Parasitol 2007; 93:60-64.

11. Pena HFJ, Gennari SM, Dubey JP, Su C. Population structure and mouse-virulence of Toxoplasma gondii in Brazil. Int J Parasitol 2008; 38: 561-569.

12. da Silva RC, Su C, Langoni H. First identification of Sarcocystis tenella (Railliet, 1886) Moulé, 1886 (Protozoa: Apicomplexa) by PCR in naturally infected sheep from Brazil. Vet Parasitol 2009; 165:332-336.

13. Dardé ML. Biodiversity in Toxoplasma gondii. Curr Top Microbiol Immunol 1996; 219: 27-41.

14. Pena HFJ, Soares RM, Amaku M, Dubey JP, Gennari SM. Toxoplasma gondii infection in cats from São Paulo state, Brazil: seroprevalence, oocyst shedding, isolation in mice, and biologic and molecular characterization. Res Vet Sci 2006; 81:58-67.

15. Sousa S, Ajzenberg D, Vilanova M, Costa J, Dardé ML. Use of GRA6-derived synthetic polymorphic peptides in an immunoenzymatic assay to serotype Toxoplasma gondii in human serum samples collected from three continents. Clin Vaccine Immunol 2008; 15:1380-1386.

16. Dubey JP, Velmurugan GV, Chockalingam A, Pena HFJ, Oliveira LN, Leifer CA, et al. Genetic diversity of Toxoplasma gondii isolates from chickens from Brazil. Vet Parasitol 2008; 157:299-305.

17. Velmurugan GV, Dubey JP, Su C. Genotyping studies of Toxoplasma gondii isolates from Africa revealed that the archetypal clonal lineages predominate as in North America and Europe. Vet Parasitol 2008; 155:314-318.

18. Trisciuoglio A, Zanet S, Marello G, Chiesa F, Nucera DM, Bergallo $\mathrm{M}$, et al. The use of loop-mediated isothermal amplification improves Toxoplasma gondii detection in wildlife. J Vet Diagn Invest 2015; 27:754-757. 
19. Machacová T, Aizenberg D, Zakovská A, Sedlák K, Bártová E. Toxoplasma gondii and Neospora caninum in wild small mammals: seroprevalence, DNA detection and genotyping. Vet Parasitol 2016; 223:88-90

20. Vitaliano SN, Soares HS, Minervino AHH, Santos ALQ, Werther $\mathrm{K}$, Marvulo MFV, et al. Genetic characterization of Toxoplasma gondii from Brazilian wildlife revealed abundant new genotypes. Int J Parasitol Parasites Wildl 2014; 3:276-283.

21. Nowak RM. Walker's Mammals of the World. $6^{\text {th }}$ edition. Baltimore: The Johns Hopkins University Press, 1999, 836p.

22. Rocha VJ, Reis NR, Sekiama ML. Dieta e dispersão de sementes por Cerdocyon thous (Linnaeus) (Carnívora, Canidae), em um fragmento florestal no Paraná, Brasil. Rev Bras Zool 2004; 21:871-876.

23. Freitas SR, Oliveira AN, Ciocheti G, Vieira MV, Matos DMS. How landscape features influence road-kill of three species of mammals in the Brazilian Savanna? Oecol Australis 2014; 18:35-45.

24. Verma SK, Minicucci L, Murphy D, Carstensen M, Humpal C, Wolf $\mathrm{P}$, et al. Antibody detection, and molecular characterization of Toxoplasma gondii from Bobcats (Lynx rufus), domestic cats (Felis catus), and wildlife from Minnesota, USA. J Eukaryot Microbiol 2016; 63:567-571.
25. Sibley LD, Khan A, Ajioka JW, Rosenthal BM. Genetic diversity of Toxoplasma gondii in animals and humans. Philos Trans R Soc Lond B Biol Sci 2009; 364:2749-2761.

26. Acha PN, Szyfres B. Zoonosis y enfermedades transmisibles communes al hombre y a los animals. $3^{\text {rd }}$ edition. Organización Panamericana de la Salud. Publicación Científica y Técnica No. 580, Washington, 2003, 413p.

27. Truppel JH, Reifur L, Montiani-Ferreira F, Lange RR, de Castro Vilani RGD'O, Gennari SM, et al. Toxoplasma gondii in Capybara (Hydrochaeris hydrochaeris) antibodies and DNA detected by IFAT and PCR. Parasitol Res 2010; 107:141-146.

28. Yai LEO, Ragozo AMA, Soares RM, Pena HFJ, Su C, Gennari SM. Genetic diversity among capybara (Hydrochaeris hydrochaeris) isolates of Toxoplasma gondii from Brazil. Vet Parasitol 2009; 162:332-337.

29. Câmara T, Murta R, Mamíferos da Serra de Cipó. Belo Horizonte: Editora PUC-Minas/Museu de Ciências Naturais; 2003. 129p.

30. Rossi RV, Bianconi GV, Pedro WA. Ordem Didelphimorphia. In: Reis NR, Peracchi AL, Pedro WA, Lima IP, editors. Mamíferos do Brasil. Londrina: Universidade Estadual de Londrina; 2006. p. 27-66. 